\title{
The Theory of Commercial Bribery Crime
}

\author{
Ran An \\ Hubei Zanda Law Firm \\ Wuhan, China
}

\begin{abstract}
The crime of commercial bribery, as its name implies, is essentially a crime of bribery, which is produced in the market. Actors in the transaction, review, approval process, secretly give good in the other side, in order to obtain the desired favorable conditions or substantial benefits. As a persistent disease of market economy, the crime of commercial bribery has not died out gradually with the perfection of the legal system and the norms of the market. It is still growing and even becoming more and more serious. In a market economy with competition as the core, we cannot deny that people's propensity to profit has become an important factor in promoting social development. Naturally, business activists are often blinded by their interests and give up their adherence to their inner bottom line. The crime of commercial bribery has become a nightmare that erodes the social and economic order.
\end{abstract}

Keywords-commercial bribery crime; investigation; commercial bribery; countermeasures

\section{INTRODUCTION}

The crime of commercial bribery destroys the normal competition mechanism of the market, causes economic disorder, damages the national, public and personal interests, breeds corruption, fosters the unhealthy trend of the society and endangers social stability. According to the data published by the Supreme people's Procuratorate in the report on its work at the National "two sessions," the statistical results show that the investigation of corruption and bribery and other job-related crimes was filed for investigation in 2014, 2015 compared with 2013. The number of cases and the number of individuals involved has increased. The number of bribing persons investigated and dealt with has shown an obvious upward trend year by year, and the proportion of the number of bribe-paying personnel investigated and dealt with has greatly increased relative to the number of bribe-taking personnel being investigated and dealt with. In 2013, the number of bribe-takers accounted for about $30.5 \%$ of the total, while in 2014 and 2015 they rose significantly, accounting for about 55.7 percent and 62.2 percent, respectively. 1 The number of commercial bribery cases is increasing year by year in a certain proportion. The crime of commercial bribery is not an incurable disease of the market economy system. As long as we carry out effective management, focus on prevention and crackdown, and carry out effective countermeasures according to the

\footnotetext{
Data source: "2015-2016 China anti-commercial bribery Research report”, http://mt.sohu.com/20160521/n450693234.shtml
}

guidance of the legal theory, we can effectively eliminate this "stubborn disease", to ensure the normal development of the economy and society and promote social harmony. It is the most urgent task to crack down the commercial bribery crime and investigate the cases that have taken place.

\section{A SUMMARY OF THE CRIME OF COMMERCIAL BRIBERY}

\section{A. The Meaning of Commercial Bribery}

The so-called commercial bribery crime refers to the behavior of the perpetrator who, for the purpose of obtaining huge commercial profits, bribed the relevant personnel of the transactional party or other relevant persons who have certain influence on the transaction, or the relevant personnel of the trading party, the act of accepting goods and making profits for others who have a certain influence on the transaction by taking advantage of their decision or influence on the trading opportunity or some competitive advantage.

As a kind of appellation of crime of commercial bribery, the general academic circles believe that the following eight kinds of crimes are involved in the crime of commercial bribery: Crime of accepting bribes by non-State staffs (Article 163), Bribery of non-State staffs (Article 164), crime of acceptance of bribes (Article 385), crime of bribe taking by a unit (Article 387), Bribery (Article 389), Bribery of units (Article 391), Crime of introducing a crime (Article 392), Unit bribery crime (Article 393).

\section{B. Characteristics of Commercial Bribery Crime}

1) The field of crime is expanding day by day:The development of the market economy, like a river, not only makes the green commerce along the coast more prosperous, but also makes the river bottom silt-commercial bribery cases, the scope of which continues to expand. At present, the areas with frequent cases of commercial bribery in China have been expanded from the original medical and construction contracting industry to the fields of government procurement, education and recruitment, and securities and finance. Among them, they are mainly concentrated in the 11 fields of engineering construction, land transfer, property rights transaction, pharmaceutical purchase and marketing, resource development and distribution, publishing and distribution, bank credit, securities and futures, commercial insurance, telecommunications, and government procurement. This is because existing laws and regulations 
have big loopholes in these areas, and suspects can make huge profits from them. In addition, the labor force, the technology market also has the tendency to become the new noticeable concentration point of bribery crime.

The crime of commercial bribery has been infiltrated into the areas of economic activities, such as engineering construction, land transfer, government procurement, property rights transactions, pharmaceutical purchase and marketing, resource development and distribution, with a high incidence of cases. This is mainly due to the shortage of resources, large profit space and fierce competition in these fields, and it's getting worse.2Our country is in the key period of reform, the market system is still not mature, the limit of government power is not obvious, and it is easy to produce side effects because of too much power while supervising the market. There are limited resources in the market. Bribery has been used as a bargaining chip in exchange for profits, and as an unfair way of competition, it has developed into a latent rule in many fields, if it is not followed by this rule, It will be difficult for business participants to gain a foothold. The cost of commercial bribery is nothing compared to the return. It is not hard to imagine that, in this environment, business participants are not repellent of bribery, even willing to accept and use its special value.

2) The specificity of the subject of crime: Cases of commercial bribery usually take place in the course of commercial exchanges and cooperation with the Government. Therefore, the identity of the perpetrator as engaged in the internal management of the enterprise, as well as in the commission or assignment of some specific business, is essential. If there is no such a specific identity, there is no possibility of using the convenience of power for the benefit of others, or the possibility of using the convenient conditions to carry out specific business operations for the benefit of others, so that there will be no crime of commercial bribery.

3) Concealment of criminal behavior: The number of criminal cases filed by public security organs has been increasing year by year, which indicates that the crackdown on crime is initially intensified, but compared with the total number of economic crimes filed in the same period, the proportion of commercial bribery crime cases has always been maintained at less than $10 \%$. Figures from the Supreme people's Court since 2014 show that the number of cases of commercial bribery concluded by the people's Court each year has remained basically stable and has not fluctuated. It can be seen that commercial bribery crime has a huge crime black number, which is a very strong hidden embodiment of commercial bribery crime. Commercial bribery often uses a "one-to-one" approach to hand over property, and no one else is involved in it. In addition, in order to evade the crackdown by the investigative authorities, the two sides also have various methods to

\footnotetext{
Li Jianguang, Zhang Denggao: "Commercial Bribery: The Pain of Infinity", in "Prosecutorial Situation", No. 11, 2014.
}

disguise their criminal acts under various pretexts. For example, the transfer of equity, the right to use vehicles, houses and other physical objects, please eat and drink, high-end entertainment consumption, overseas travel and entertainment, as well as a variety of consultancy fees, Consulting fees have even become a "safe passage" for commercial bribery 3 , The most important point is that the crime of commercial bribery is carried out secretly outside the account, and the flow of funds can not be reflected in the accounts, which greatly increases the difficulty of finding the crime and obtaining evidence.

\section{The Causes of Commercial Bribery Crime}

In a sense, market economy means competition. But in today's society, some competitive operators take commercial bribes in order to take shortcuts and violate the rules of market competition. As our country is still in a special historical period of economic transition, social transformation, the further deepening of the reform and the adjustment of the economic and social structure, the loopholes in economic life, the defects in legislation, and the huge temptation of illegal economic interests, The lack of good faith, imperfect government management and so on will still exist in a large number, so the factors inducing commercial bribery crime will further increase, and the situation of commercial bribery crime is still grim.

1) Lack of morality in Market activities: Market competition, generally speaking, is obviously more focused on the quality of goods, prices and service levels of operators. In the process of competition, through fair comparison, the survival of the fittest is realized, thus promoting the healthy development of social economy and realizing the virtuous circle. Although business management is the top priority of the enterprise, improving traditional technology and improving the quality of its products or services can lead to a more competitive position in the market. But in fact, there are still a lot of market subjects to pursue their own interests by means contrary to the normal market mechanism. With the increasing competition in the market, in order to seek more benefits and reduce operating costs, some operators have chosen unfair competition in their business activities, in order to secretly obtain trading opportunities and sell their own products or services, or buy goods or accept services on more favourable terms than others. But the recipient of interest, unable to resist the temptation, is driven by lucky psychology to act against the market morality, destroy the fair competition mechanism of the market, and cause considerable losses to others and the society. For both sides of the crime of commercial bribery, this is obviously a reflection of the lack of morality in market operation activities.

2) A great temptation to profit: Power concentration, capital intensive, scarce resources, strong monopoly and

Li Bingyang, Wang Lai, Yang Yujie: "Investigation of Commercial Bribery Crimes”, in Public Security Research, No. 10, 2010 
fierce competition in the field of industry, the incidence of commercial bribery crime is relatively high, all of which contains a huge commercial profit space. Even if the operator pays more attention on the quality, price, cost and after-sales service of the product, he should focus on improving the production efficiency and the technical content of the product, and devote himself to improving the ratio of performance to price of the product, so as to participate in the fierce market competition. The higher the cost, the greater the market risk, because if the expected results are not achieved, the previous investment will be lost. Therefore, in the face of huge interest temptation, bribegivers tend to choose a more secure way-bribery. As long as you pay a lower cost, you get high returns: get project approval, become a monopoly agent, get a large government procurement contract, reduce production costs, etc., while the bribe-takers are desperate to fill it. Willing to use the power in hand in exchange for benefits, makes the former rot and continue. ${ }^{4}$ This is also the breeding ground and conditions for commercial bribery.

3) Weak supervision by government departments: The imperfection of government supervision is mainly reflected in the administrative license and administrative contract, which is more prominent in finance, construction, communication, medicine and other industries. It mainly shows that the administrative power interferes too much with the fair competition in the market, the government interferes too much with the enterprise affairs, the efficiency of administration according to law is low, the laws and regulations of supervision are not perfect, the power is centralized, and the supervision of monopoly industry is weak, local protectionism, etc. On the other hand, there are many law enforcement subjects of commercial bribery crime, not only the public security organs and procuratorial organs have the power to enforce the law, but also the auditing department, the industry and commerce administration department and the discipline inspection department can carry on the law enforcement to the commercial bribery crime (advance law enforcement). Too many law enforcement subjects tend to increase the liability of unclear, different standards of law enforcement and increase the cost of law enforcement and other adverse factors, so that the supervision of commercial activities is hindered, more likely to lead to the commercial bribery crime in the dark breeding.

\section{The Pattern of Commercial Bribery Crime}

1) Classification by point of time: Bribery in advance, afterwards, in advance and afterwards are the four main aspects of the crime of commercial bribery, which is based on the classification of bribery, extort bribes and the use of power to make improper acts and to obtain illegal benefits.

4 Ma Zhenggang. Preventing Commercial Bribery from the Source, China Supervision, No. 21, 2012
Prior bribery, that is, before obtaining the desired benefit or in the course of a commercial activity, in order to obtain a favourable competitive position, obtains a commercial opportunity, increase remuneration, make supervision and inspection muddle through the border or engage in illegal activities, Bribery is offered on the authority of the bribetaker. Ex post bribery refers to the criminal activity in which the bribe-taker uses his authority to help him to obtain an illegal benefit after the occurrence of the act, in the name of giving thanks to the bribe-taker, and for the sake of the later interests at the same time, expect to use the power and position of bribe-takers to gain more opportunities for illegal interests. Ex post bribery refers to the criminal activity in which the bribe-taker uses his authority to help him to obtain an illegal benefit after the occurrence of the act, in the name of giving thanks to the bribe-taker, and for the sake of the later interests at the same time. Expect to use the power and position of bribe-takers to gain more opportunities for illegal interests. Prior to asking for bribes, that is to say, the person who asks for bribes is explicit or implied to them before the actual action, in order to help them solve the problem, give them the advantage of opportunity and other reasons as the condition, asking for bribes. Ex post bribery is a person with relevant authority or low latitude to ask for bribes, for the commercial activities of bribing people to create obstacles or do not take the initiative to perform the power of reducing obstacles, on the contrary, or directly request bribes. Similarly, some middlemen to introduce business, matchmaking for business fees or kickbacks, are also a commercial bribery crime.

The time choice of soliciting bribes in commercial bribery crime cases has a certain randomness, and tends to make use of normal contact opportunities to carry out preliminary communication and then to continue the interactive activities of illegal interests in private. 5 Commercial bribery has relative stability in space. For the privacy and concealment of illegal transactions, both sides will choose one-to-one, face-to-face negotiations as far as possible, so the high probability of trading places will choose places both sides are familiar with, for their own safety considerations, and there is no unnecessary risk.

2) Behavior classification: Compared with ordinary bribery cases, commercial bribery cases are more likely to engage in illegal transactions in the name of legal and normal communication, and it is more likely not to be discovered. The variety of business names and the imperfections of the regulatory system provide more room for development of the "darkness in the sewers." According to the nature of the accepted interests, it can be summarized as rights and money transactions, rights transactions, equity transactions.

a) The crime of commercial bribery in the form of trading of power and money: Power and money trading is the most common form of commercial bribery crime.

Liu Shenshi. Characteristics of Commercial Bribery Cases and Countermeasures for Investigation, Journal of Sichuan Procuratorial College, No. 5, 2013 
Money is more efficient as a bargaining chip for bribery than other interests, after all, money remains "universal" in most cases. In business activities, service and labor for remuneration is one of the basic principles of the market economy. Therefore, bribe-givers secretly use various seemingly reasonable fees to cover up illegal transactions. In addition, bribery in the form of loans and interest payments is a common practice. Debtor creditor relationship in business is itself more complex. The bribe-taker usually obtains money from the briber in the name of borrowing money, but there is neither a loan contract nor an agreement on interest, repayment time, and no sign of repayment, whether or not he has the ability to repay. Moreover, the briber forgives all or part of the debt for the recipient without reason, directly benefiting him. What's more, money is paid to the recipient in the name of paying interest on the loan, but in fact there is no loan relationship between the two. In addition, in overseas and foreign bribery cases, it is common to accept bribes in the name of buying gifts and foreign exchange.

b) The crime of commercial bribery in the form of dealing in property: Under certain conditions, it is not convenient for the bribe-giver to give the bribe-taker money and property benefits directly, so he often changes his direction, with some special time points, gives it what he likes, and presents gifts of considerable value. At the time of giving, the bribe-giver will express or imply his purpose, while the bribe-taker will appreciate it, give the corresponding guarantee to him in person or afterwards, and then complete the briber's "entrustment" with practical action. Trading in title is more difficult in obtaining evidence than trading in power and money. Because it is normal to give gifts to each other in the field of business activities, it is a special way to express trust, and it is more difficult to distinguish between the real gifts with the nature of commercial bribery. Of course, cases related to state functionaries are subject to detailed and strict laws and regulations, making it easier to obtain evidence.

c) The crime of commercial bribery in the form of rights and interests transaction: Commercial bribery in this way is more hidden than the first two. The interests mentioned here do not necessarily belong to property or material interests, but they are more indirect and need deeper investigation and evidence to determine the bribery relationship. Specifically, the bribe-giver invites the bribetaker to take part in recreational activities together; borrows the house to the bribe-taker to live, borrows the car for the bribe-taking person, but does not charge rent or nominal rent that does not match the market price; and even provides sexual services. In order to obtain illegal interests, they all belong to the representative form of rights and interests trading. Taking advantage of the special environment of commercial activities, the bribe-takers often choose the methods of "engaging in stock" and "managing money by agent" and so on. Both sides may even sign a formal and legal agreement as a cover, in the name of partnership and financial agency, but the bribe-takers enjoy significantly more than they can afford to invest. The bribe-taker will not take part in the management and decision, and will not take any corresponding risks, he is a nominal shareholder and investor. The special relation of the bribe-taking person receives benefits instead of the bribe-taking person, which is also a form of equity transaction. The briber arranges suitable jobs for the bribe-takers' special associates, whether they go to work or not, and gives them high wages and bonuses. This approach can even legalize bribery on the books, often putting investigative agencies in trouble.

\section{CONCLUSION}

The crime of commercial bribery generally belongs to the crime of high intelligence and has a strong concealment. It is very difficult to investigate and solve the crime and it is difficult to obtain the evidence. Moreover, this kind of crime arises from the production and operation of enterprises and the course of market transaction. The effect of detection and punishment has a direct impact on the effective operation of the market economy mechanism of our country. Therefore, a deeper analysis of the crime of commercial bribery is a very important link in the system of punishment and prevention of corruption, which is of great significance to the establishment of a long-term mechanism against commercial bribery.

\section{REFERENCES}

[1] Yao Li. Criminal procedure law. 2nd ed. Beijing: China legal Publishing House, 2012.

[2] Chen Jun. Analysis of typical cases of law. Harbin: Harbin Engineering University Press, 2009.

[3] Shi Yuqin. A study on the legal system of controlling Commercial bribery. China Procuratorial Press, 2008.

[4] Liu Zhiyuan.A judicial guide and case study on the new type of bribery crime. China Fangzheng Press, 2007 (3): 63-65.

[5] Long Zongzhi. Criminal proof responsibility and presumption. China Procuratorial Press, 2009

[6] Long Zongzhi. Theory, system and method of evidence Law. Law Press, 2008: 151-152.

[7] Yin Jiuxin. Countermeasures for investigating bribery crimes. China Procuratorial Forum, 20042: 101-104.

[8] Yang Jiman.Innovation and practice of report clue management mode. Peopleundefineds Procuratorate, 2006 (10): 87-88.

[9] [USA]Auguste Berquez. 1995. Commercial and political bribery [J]. Legal Translation (5)

[10] C.Perelman. Justice, Law and Argument, D.Reidel Publishing Company, 1980, 1

[11] D.d Raphael,Justice and liberty Athloner Press 1980, 95. 